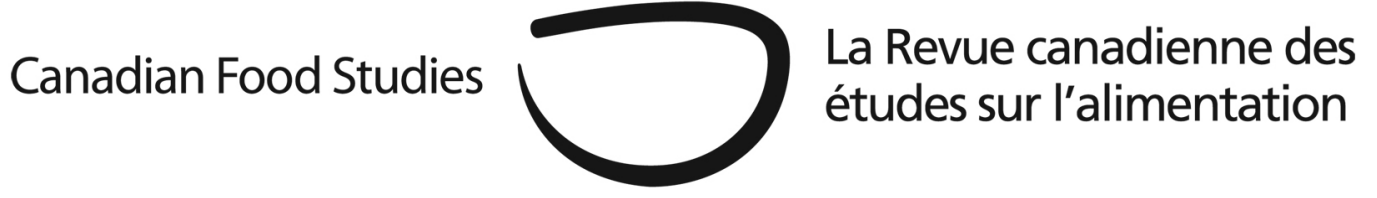

Original Research Article

\title{
Constituting community through food charters: A rhetorical-genre analysis
}

\author{
Philippa Spoel ${ }^{\mathrm{a}}$ and Colleen Derkatch ${ }^{\mathrm{b}}$ \\ aProfessor, Department of English (Rhetoric and Media Studies), Laurentian University \\ ${ }^{b}$ Assistant Professor, Department of English, Ryerson University
}

\begin{abstract}
Communities across Canada are increasingly developing food charters, with at least 22 regional charters published in Ontario alone. As a rhetorical genre, food charters are persuasive actions that articulate not only the kind of food system to which a community aspires, but also the kind of community that it aspires to be. We argue that Ontario's food charters play an important role in constituting a sense of community identity and values through the rhetorical action of the genre itself. We analyze how this is accomplished through two rhetorical features, the naming of community and the listing of community priorities, showing how these features simultaneously obscure and reveal ideological tensions and logical incongruities within each community's vision for its food system. Our analysis illustrates how the genre of the food charter both responds to and shapes the diverse, possibly conflicting values that inform food policy and food security initiatives in Ontario, and it offers insight into how the genre itself may inadvertently constrain the action it is intended to perform.
\end{abstract}

Keywords: food charters; food policy; public health discourse; critical food studies; discourse studies; genre theory; rhetorical analysis 


\section{Introduction}

Food charters, as a genre, are intended to be non-binding visioning documents that address issues of food security and food sustainability within communities. Following the lead of Toronto, which endorsed the first Canadian charter in 2001, an increasing number of communities have crafted or are currently crafting their own charters as part of the growth of municipal and regional food policy initiatives across Canada (MacRae \& Donahue, 2013, p. 22). Ontario alone currently has at least 22 completed regional food charters, with others under development. ${ }^{1}$ Each of these charters addresses a community defined not primarily by municipal boundaries but by the regional boundaries of one of the province's 36 Public Health Units (PHUs). ${ }^{2}$ According to MacRae and Donahue (2013), significant factors motivating the development of Ontario's regional charters include the growing inclusion of food security within the province's public health program requirements along with recent revisions to its Public Health Standards (p. 22).

As rhetoricians of health and medicine and as critics of neoliberal public health discourse, we are interested in how Ontario's PHUs have begun to incorporate the discourse of local food into their promotion of healthy lifestyles (Derkatch \& Spoel, 2015). Through this research, we discovered that food charters figure significantly — though ambiguously — within PHU-linked communication materials that promote "local food" as a valuable component of healthy living and healthy communities. Although Ontario’s food charters typically are composed by multisector/multi-participant community networks (e.g., local food councils), PHUs have been and continue to be closely involved in their development, whether by leading their creation or by participating actively in the networks doing so.

Ontario's food charters address matters of community health and well-being in multiple ways. As "aspirational” documents aimed at guiding the development of local food systems (Runnels, 2012; Dillon Consulting, 2013), they promote the ideals of food security, healthy eating, a healthy environment, and a healthy economy for the whole community. We argue in this paper that they also play an important role in fostering a sense of community identity and values through the rhetorical action of the genre itself. As an emergent text type with a nowconventionalized form and content, the food charter genre contains embedded values about the communities that produce it. Understanding how these values are produced and how they affect the communities they address yields important insight into the ways that the genre of the food charter itself may inadvertently constrain the action it is intended to perform.

\footnotetext{
${ }^{1}$ Regions and cities with completed charters include Bruce Grey; Durham; Elgin-St. Thomas; Guelph-Wellington; Halton; Hamilton; Huron County; Kawartha Lakes; Kingston, Frontenac, Lennox, and Addington; Leeds, Grenville, and Lanark; London-Middlesex; Northumberland County; Oxford County; Parry Sound and Area; Sarnia-Lambton; Simcoe County; Sudbury; Thunder Bay; Toronto; Waterloo Region; Windsor-Essex; and York. Charters currently under development include Algoma District; Nipissing and Area; and Peel Region.

${ }^{2}$ Public Health Units (PHUs) provide Ontarians with health promotion and disease prevention programs on, for example, healthy living, communicable diseases, vaccination, food safety, and child growth and development. There are 36 PHUs across Ontario, each governed by a Board of Health and jointly funded by local municipalities and the provincial government (Ontario Ministry of Health and Long-Term Care, 2014).
} 
Existing policy and scholarly reviews of food charters emphasize their role in building community—particularly because, proponents suggest, charters are necessarily composed collaboratively by multiple local stakeholders who, together, establish the community's vision of its desired food system (Dillon Consulting, 2013; Hardman \& Larkham, 2014; Jaquith, 2011; Metzger \& Aurini, 2013). By contrast, from a rhetorical perspective (which focuses on how meaning and action are produced in discourse), we are led instead to inquire how food charters work to constitute community identities and values, rather than simply to reflect existing identities and values.

In this article, we approach food charters as persuasive actions that articulate not only the kind of food system to which a community aspires, but also the kind of community that it aspires to be. We see the food charter as an epideictic genre, a persuasive form that operates in the realm of values through the actions of praise and blame. We propose that one of the food charter's main functions is to praise the community to itself: to construct for the community an aspirational vision of itself as possessing a shared identity and coherent set of shared values for guiding the development of its local food system. As our analysis below demonstrates, the genre enacts this epideictic, aspirational function through two significant discursive features: naming who the community is and listing the community's shared priorities for its regional food system. By analyzing closely how these two rhetorical features operate, we show that both simultaneously obscure and reveal ideological tensions and logical incongruities that inform the community's vision for its food system.

We begin by outlining our key topics and texts and our theoretical approach of rhetoricalgenre analysis (Bawarshi \& Reiff, 2010; Miller, 1984). In the analysis that follows, we draw on Burke's (1966) concept of “terministic screens” to trace how community is named in Ontario food charters as a way of understanding how these documents shape and sometimes cloud community identity. We then work with Perelman and Olbrechts-Tyteca's (1969) model of quasi-logical argumentation to show how lists in food charters create a sense of coherent connection among the diverse and potentially conflicting values and priorities within each community's vision for its food system. Our analysis illustrates some of the specific ways in which food charters, as a genre, both respond to and shape the diverse and possibly incompatible range of values that informs contemporary public discourse on health, local food, and food security in Ontario.

\section{What are food charters?}

Over the 15 years since Toronto advanced the first food charter in Canada, the genre has stabilized enough that we can now identify some of its characteristic rhetorical features and the values embedded within it. Although there are variations in form among individual food charters, they are typically one to two pages long and begin with a preamble that articulates a set of core 
beliefs, rights, and goals (see examples in Figures 1 and 2 on the following pages). ${ }^{3}$ The opening statement is followed by an overarching list of core values for the community's food system. Under each of the core values are bullet-point lists of specific objectives or endpoints for what the enactment of those values would entail. ${ }^{4}$

The character and purpose of food charters are harder to pinpoint but researchers, policymakers, and food-system stakeholders generally agree that a food charter is a vision statement that articulates a community's “values, principles, and priorities” concerning its food system (FoodNet Ontario, n.d.; see also foodcoreLGL, n.d.b). As vision statements, food charters are aspirational documents in the sense that, as Runnels (2012) argues, they "are not typically directed toward action but are declarations of important beliefs that help set the tone for other policy documents” (p. 15). Similarly, Dillon Consulting (2013) notes that,

Food Charters do not usually contain prescriptive policy statements and are not binding in any fashion. Indeed, Wayne Roberts, a recognized food policy expert...stressed that Food Charters should be “purely aspirational.”...Food Charters are intended to offer decision-makers, community groups or individuals an overall guide for shaping food-related policy and projects. (p. 3)

We argue, however, that although food charters do not provide "prescriptive policy statements," they do prescribe certain values that are ultimately intended to influence policy.

One such motivating value, key for this paper, is the principle of food security which, according to the UN Committee on Food Security (2013), means “when all people, at all times, have physical, social and economic access to sufficient, safe and nutritious food that meets their dietary needs and food preferences for an active and healthy life” (p. 2). Jaquith’s (2011) assessment of Canadian food charters foregrounds the centrality of this value to the genre: "A Food Charter is a statement of values, principles, and priorities for a just and sustainable food system that will promote health and food security for all” (p. 6, emphasis added). ${ }^{5}$

\footnotetext{
${ }^{3}$ Of 22 Ontario food charters, 17 are 1-2 pages long, formatted as either a full-page letter or three-panel brochure. Four of the remaining charters are 4 pages and one is 6 . All but one of these 22 charters begins with a preamble.

${ }^{4}$ All but one of the 22 charters contains a list of core values or priorities with sub-points.

${ }^{5}$ Of the 22 charters we analysed, 10 explicitly use the phrase "food security" or "community food security.” For fuller discussion of the concept of “food security” in Canada, see Martin and Andrée (2014); Power (2008).
} 


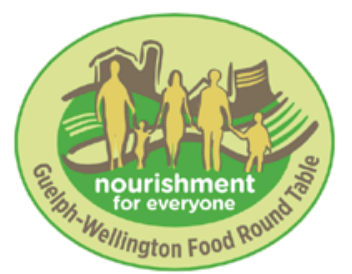

\section{Guelph-Wellington Food Bharter}

The United Nations Covenant on Social, Economic and Cultural Rights acknowledges the right for all to have access to adequate food. Furthering this basic tenet, we will work together to build a vibrant, sustainable, food-secure community. We, the undersigned believe the following principles are key priorities as we create a just and sustainable food system for all. As signatories to this food charter, we commit to entering into a dialogue on actions based on these principles.

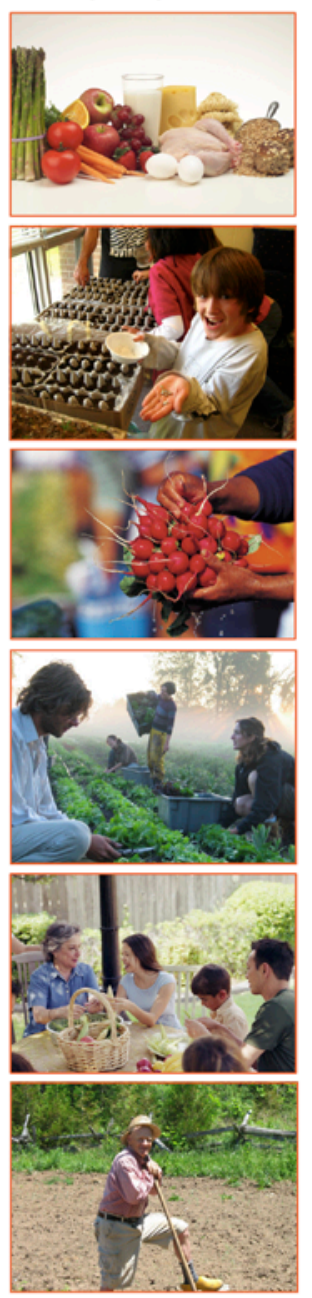

Because we value Health, we support...

- Public policy that recognizes food's contribution to physical, mental, spiritual, and emotional well-being.

- Neighbourhoods that encourage walk-able and bike-able access to healthy food.

- Strategies to prevent and manage chronic diseases through access to affordable healthy food.

Because we value Education, we support...

- Initiatives that develop food skills.

- Programs that train future farmers.

- The integration of food literacy and gardening into school curricula.

- Public education about the connections between our health, the environment, and our food choices.

Because we value Sustainable Economic Development, we support ...

- Prioritizing production, processing, distribution, and consumption of local food.

- Promoting our region as a food, agricultural, and culinary destination.

- Advancing food and agriculture research and innovation for alternative food systems.

Because we value Envilronment, we support...

- The preservation of local farmland that protects watersheds and wildlife habitat.

- The growth of food production methods that sustain or enhance the natural environment in both rural and urban settings.

Because we value Bulture, we support...

- Celebrating and promoting respect for traditional, cultural, and spiritual food diversity.

- Enhancing the dignity and joy of growing, preparing and eating food.

- Strengthening links between rural and urban communities.

Because we value Social Justice, we support...

- Identifying healthy food as a social good and ensuring access regardless of income.

- Championing a fair wage for the production of food, and a safe and respectful environment for all food workers.

- Helping to ensure land access for new farmers for the growing of food.

- Advocating for income, education, employment, housing and transportation policies that support access to healthy, sustainable food.

\section{If you support the Charter's values, please sign our petition. Go to www.gwfrt.com or write info@gwfrt.com}

Figure 1: Guelph-Wellington Food Charter, Guelph-Wellington Food Roundtable (2011). Reprinted with permission. 


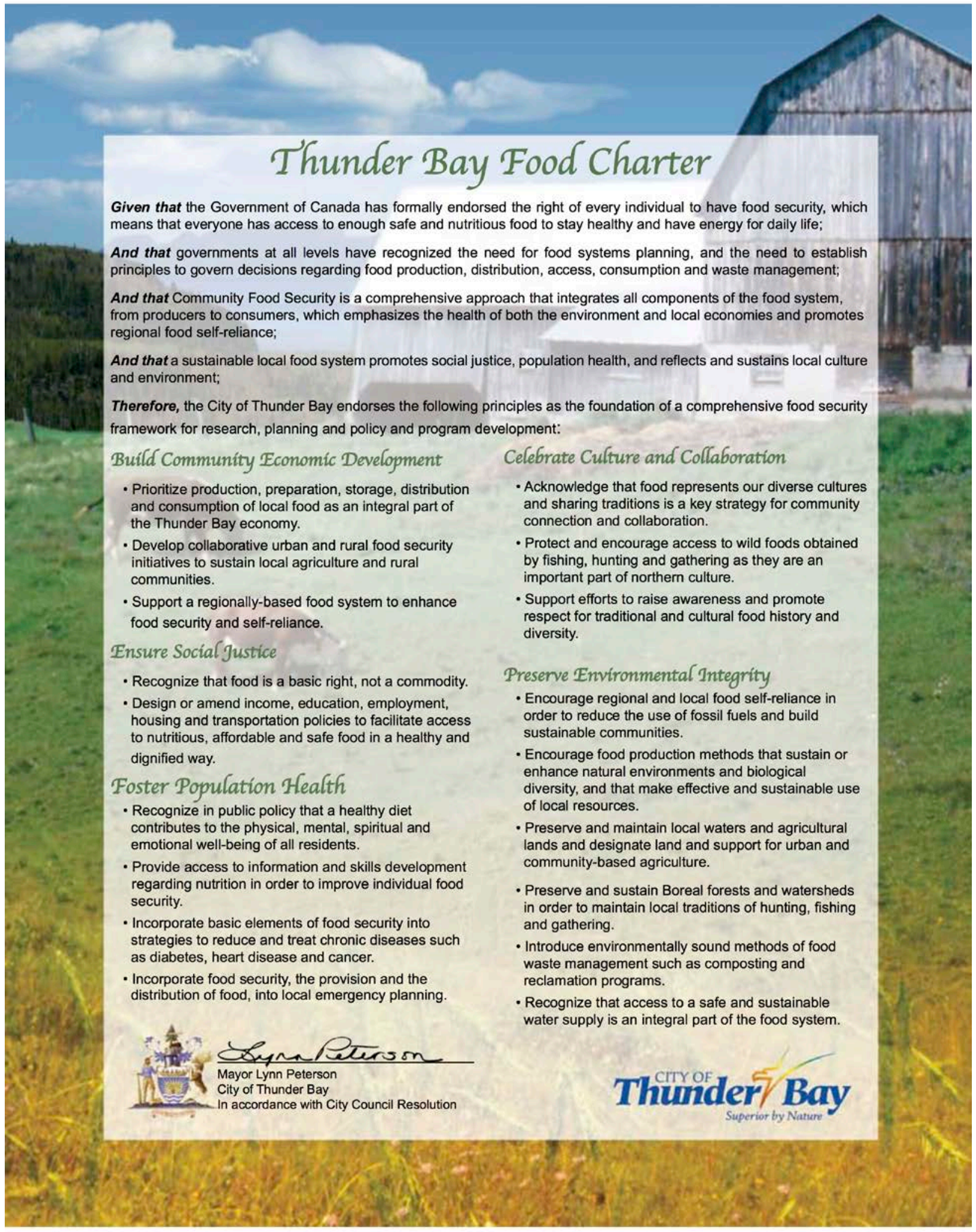

Figure 2: Thunder Bay Food Charter, Thunder Bay Food Action Network (2008). Reprinted with permission of the Thunder Bay District Health Unit. 


\section{Methodology: A rhetorical-genre approach to food charters}

For our analysis, we gathered all 22 currently published food charters in Ontario. ${ }^{6}$ This sample represents almost two-thirds of Ontario's 36 PHU areas and includes charters from all regions (Central, Southeast, Southwest, Northeast, Northwest, and Greater Toronto) and from rural, urban, and mixed rural-urban communities. The majority of these charters have been produced since $2010 .^{7}$ In the first stage of our research, we independently reviewed the charters to determine what recurring features of the genre appeared most salient. This preliminary analysis led us to identify the constitution of community identity and values as a key social action of the genre, which is accomplished through the rhetorical features of naming community and listing priorities. We then systematically reviewed each of the 22 currently published charters to determine whether or not they possessed these features, and if so, in what terms (see Appendix). These features inform our analysis of community identity and values below.

Approaching Ontario food charters from the perspective of rhetorical-genre theory allows us to foreground the shared yet situationally distinctive features and functions of the rhetorical actions they perform. Rhetorical-genre theory approaches language-use as a form of action that shapes rather than simply reflects the world. A rhetorical approach to genre focuses on the "social action" that genres perform in their contexts of use (Miller, 1984). More specifically, genres can be understood "as typified ways of acting within recurrent situations, and as cultural artifacts that can tell us things about how a particular culture configures situations and ways of acting” (Bawarshi \& Reiff, 2010, p. 78).

Analyzing formal and textual features of the genre allows us to understand, in part, how the social action of a genre is performed. We argue here that a key action performed by current Ontario food charters is to constitute community values and identities. At the same time, however, we find that the structural features of the genre itself may impede the very action that the food charter is intended to perform: namely, to produce meaningful social-structural change within the food system. Rhetorical-genre theory emphasizes that genres function as complex and contestatory sites of ideological expression and negotiation, especially within institutional contexts and discourses — such as, for example, healthcare agencies. Arguing that "ideology, as manifested in institutional practice, is fragmented and conflictual, so that no single, unadulterated ideological perspective prevails entirely” (Paré, 2002, p. 59), Paré claims that genres are key sites of ideological struggle within these contexts of "competing visions and values being advanced, challenged, negotiated, and altered” (p. 59). Our analysis below indicates that, although food charters, as a genre, constitute "community" as place of caring and sharing, they contain within them "competing visions and values" for that community that may impede their successful implementation within policy settings.

\footnotetext{
${ }^{6}$ This did not include charters under development (e.g. Nipissing and Area). See footnote \#1 for a list of Ontario regions and cities that have food charters.

${ }^{7}$ The exceptions are Toronto (2001), Sudbury (2004), Thunder Bay (2008), and Durham (2008).
} 
The rhetorical concept of meta-genre offers a particularly generative way of thinking about the social-ideological actions that food charters perform and how food charters operate within a larger network of interrelated genres. According to Giltrow (2001, p. 190), meta-genres are "situated language about situated language," such as institutional guidelines or policy directives. Meta-genres enable action but they also constrain it, "ruling out certain kinds of expression, endorsing others” (Giltrow, 2001, pp. 190-191). Charter documents, for instance, function as meta-genres. As McCarthy (1991) notes in her study of diagnostic manuals in psychiatry, “The charter document of a social or political group establishes an organizing framework that specifies what is significant and draws people's attention to certain rules and relationships. In other words, the charter defines as authoritative certain ways of seeing and deflects attention from other ways. It thus stabilizes a particular reality and sets the terms for future discussions” (p. 359). As charter documents intended to guide community food policies and practices, food charters therefore function as a meta-genre because they are situated rhetorical actions aimed at shaping other rhetorical and material actions (e.g., community policies and actions).

One such action performed by food charters is the act of naming: they shape how the community names itself and its values. This notion of community is the point out of which emerge all future actions anticipated and entailed by the food charter as a meta-genre. At the same time, however, as sites of ideological struggle (Paré, 2002), meta-genres may enact and contribute to_-rather than resolve- “dissonances and contradictions” within the larger institutional or socio-political contexts from which they arise and to which they respond (Schryer \& Spoel, 2005, p. 257). As our analysis of food charters illustrates, these kinds of tensions can be traced, at least in part, through the terminologies and argumentative structures that the documents employ to characterize community identity and values. We take up each of these elements - terminologies (as “terministic screens”) and argumentative structures (as "valuelists”)__over the remaining sections of this article.

Analysis

Who is "community"? Terministic screens in food charters

Burke’s (1966) concept of “terministic screens” helps to explain how the notion of community works rhetorically in food charters because his concept foregrounds the role of language in filtering or shaping our understanding of reality. The different terminologies that rhetorical actors use to name the world work like photographic filters by reflecting, selecting, and deflecting different aspects of reality (Burke, 1966, p. 45). Analyzing terministic screens illuminates the specific motives, values, and assumptions that shape individual or group worldviews (Spoel \& Den Hoed, 2014). In the case of food charters, the terminologies used to 
describe who the community is at once reflect, select, and deflect particular interpretations of who the community is assumed to be.

One compelling feature of the food charter genre is that charters are not only created for communities but also by communities - or, more accurately, by community stakeholders. The community is therefore both the author and the primary intended audience of the genre. ${ }^{8}$ How then do these documents name these two overlapping but distinct senses of community? In this section, we examine the terministic screen of community by tracing how food charters invoke specific and varying characterizations of community as both author and addressee of the food charter genre.

\section{Building values; building community}

Most discussions of food charters praise charters as a means both to represent community values and to strengthen community engagement and relationships. According to Jaquith (2011), “a Food Charter represents the voices and visions of community members, resulting in a communityowned and locally focused action plan to improve food access and sustainability" (p. 6, emphasis added). Reflecting a shared “vision” for a community's food system, food charters are therefore conceived, primarily, as the antecedents for and motivators of collective action through policy development and implementation, guided by the values of the community itself.

In addition to facilitating value-driven action, food charters are also viewed as helping to connect and build community. The process of developing a food charter necessitates collaboration among individuals and groups with diverse and possibly competing interests to create one shared vision or set of values. As foodcoreLGL (n.d.a), the Leeds, Grenville, and Lanark food charter working group, puts it, “A Food Charter brings together people and organizations that have interests in different parts of the food system and helps them to develop a common language and vision so that they can work together” (n.p., emphasis added).

Once developed, food charters are intended to guide policy and programming that foster community engagement and connection in a range of food system activities (e.g., bringing people together to celebrate food and to make community gardens; fostering relationships between producers and consumers). On the development of its own charter, for example, York Region (2012) explains that a food charter is "a tool to connect and engage all community stakeholders in working together to actively shape healthier . . . communities.” Its main benefits include "Increased cooperation and collaboration stemming from the food charter creation process" and "Increased civic engagement" across the community once the charter has been developed (p. 5).

\footnotetext{
${ }^{8}$ In Runnels’s terms, these are the “stakeholders” and the "beneficiaries” (p. 17).
} 


\section{"Community" as rhetor}

The community as author, or rhetor, of the food charter - that is, those who have collaborated in a charter's creation—often is not identified explicitly. ${ }^{9}$ While several charters do name the community groups and representatives who created the charter or oversaw its development, more than half of Ontario's published charters require searching beyond the documents themselves to identify the specific stakeholders involved in their production. ${ }^{10}$ The emergent trend of compiling online "signatory" lists that complement a charter but exist independently from it further complicates questions of authorship. ${ }^{11}$ Are the organizations and individuals who endorse a given charter by adding themselves to these online lists its rhetors - its agents—or its audience —its intended beneficiaries? Or are they both?

Within Ontario charters, the community that authored each is most commonly identified inclusively, as a collective, by first-person plural pronouns:

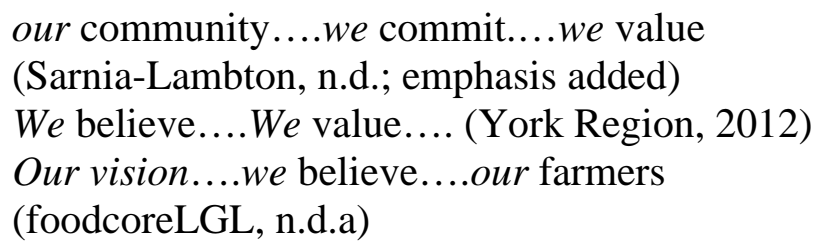

Notably, a number of recent Ontario food charters adopt the recurring phrase Because we value/believe $x$, we support $y$ to introduce each of the community's priorities for its food system. The following examples illustrate this phrasing (emphasis added throughout):

"Because we value Education, we support...initiatives that develop food skills” (Guelph-Wellington, n.d.)

"Because we value HEALTH, we support...food as an essential component to physical, mental, emotional and spiritual well-being” (Sarnia-Lambton, n.d.)

\footnotetext{
${ }^{9}$ This is contra Runnels (2012), who recommends that communities developing food charters clearly identify the organizational source of the document as well as its specific authors to foreground their differing needs and interests rather than obscure them, to reduce potential tensions or conflicts among them. We reflect on the implications of this lack of identification in the conclusion.

${ }^{10}$ Six charters identify specific stakeholders or community representatives involved in their creation; eight identify a collective author such as a food policy council or network; six include no explicit authorship attributions; and two indicate the City or municipality as authorizer but not necessarily as author.

${ }^{11}$ Four charters invite individuals and groups to endorse the charter online, whereas another includes a signature space on the document itself. An additional charter refers to "signatories" in its preamble but that seems to refer to the document's authors.
} 
"Because we believe in fair, environmentally sustainable, livable [sic], and economically profitable rural and urban communities ...we support community economic development” (Waterloo Region, 2013)

The "we" in these examples is positioned as the authorizing agent of the charter and hence as holding the power to articulate what the whole community wants and needs, and what values it aspires to enact. The use of the first-person plural creates an inclusive tone, establishing a sense of community togetherness, personalization, and belonging. Its generality means that no one is explicitly deflected or excluded from "our" community. As a result, the line is blurred between the community representatives who have authored the charter and the broader community to whom the charter is addressed. Exactly who makes up "we" typically is not clear.

\section{"Community” as audience}

Given that the terms "we” and "our” ambiguously conflate the identities of community as rhetor and community as audience, how else-if at all—is the latter kind of community named in Ontario food charters? What kinds of people are included within each charter's scope as the "community" that it addresses? Examining from this perspective the relevant terms that name community reveals two main types of terms: on one hand, the audience-community is named through broad collective nouns that function as inclusive umbrella terms, and on the other hand, community is characterized according to a range of specific demographic groups or community sectors. There is not one "community" addressed by food charters, then, but numerous often overlapping and sometimes possibly conflicting communities.

Regarding inclusive umbrella terms, all Ontario charters use some kind of universal term such as "everyone" or "all” to name the beneficiaries of the food charter. The term "all" is sometimes used as a collective noun on its own, such as in the Hamilton food charter titled "Food for All," and sometimes as a modifier of other collective nouns, as in phrases such as "all residents” (Halton, 2010) or “all members of our community” (KFL\&A Healthy Eating Working Group, 2012). This manner of collective-naming reflects and reinforces the central goal of food charters to promote food security for all community members, a goal established initially by the Toronto Food Charter's (2001) opening reference to “the fundamental right of everyone to be free from hunger” as stated by the United Nations 1976 Covenant on Social, Economic and Cultural Rights (emphasis added). When naming their community as a collective whole, some subsequent Ontario food charters continue to cite this Covenant as a guiding framework (e.g., Guelph-Wellington, 2011; London, 2011), while others refer more implicitly to its rights-based discourse of food security for all (e.g., Halton, 2010).

These broad collective nouns are counterpointed, however, by the naming of multiple individual community sectors or demographic groups to whom the charter is addressed. Specifically identified groups/sectors range from "farmers," "food workers," and "retailers" to “consumers,” "gardeners,” “families,” and “youth and students.” Organizations such as 
"businesses,” "schools,” “workplaces,” “public institutions,” and "local governments” also are identified. This terministic screen of "community” selects, and therefore segments, the kinds of community members included within the purview of each charter. Because this naming gives particular sectors rhetorical "presence" within the documents (Perelman \& Olbrechts-Tyteca, 1969), it suggests that they — rather than other unnamed sectors-are the charter's main beneficiaries.

By tracing how community is named and segmented in Ontario food charters, our analysis foregrounds an ideological tension between the social justice goal of ensuring food security for all people and the more neoliberal, marketplace goal of developing local food systems as a mode of regional economic development. Ontario food charters give strong rhetorical presence to the farming, food production, and retailing sector through terms such as "producers," "growers," "processors," “distributors,” and "retailers,” as well as "food workers,” "businesses," and "restaurants." To the extent that food charters are concerned with the development of local food systems, naming these sectors constitutes an essential feature of the food charter as genre and represents a politically significant counter to the industrialized, transnational agri-food economy. Taken together, however, these terms foreground an entrepreneurial, commodity-based approach to the food system that does not easily align with the principles of food security and sustainability rooted in social justice and community welfare.

Rather than actively resisting the neoliberalization of agriculture/food production, we argue that food charters' rhetorics of regional economic development implicitly support a “market-based 'solutions”” approach to social ills (Martin \& Andrée, 2014, p. 173). Tellingly, Ontarians typically are positioned within the language of the charters as economic actors"consumers"-rather than as beneficiaries of a system that ensures "food for all." Further, although "farmers" and "food workers" are positioned as socioeconomically disadvantaged groups within the charters, other vulnerable groups such as those who are homeless, elderly, have little or no income, or are living with disabilities or physical or mental illness are conspicuously absent. ${ }^{12}$ Those most likely to experience food insecurity are generally represented only implicitly, hidden from direct view under catch-all terms such as "all” or "everyone."

As a result, the rights, needs, and wishes of a community's most vulnerable members may be overlooked or under-represented in the creation of these policy-governing documents (Runnels, 2012). ${ }^{13}$ Even if food security is stated as an explicit goal of the genre, blanket references to the rights and needs of "everyone" and "all” enfold the rights and needs of those most vulnerable to food insecurity within broader and largely consumer-driven rhetorics of access, agency, and choice. The most prevalent terministic screen of "community” in Ontario

\footnotetext{
${ }^{12}$ Exceptions are the Toronto (2001) and London (2011) charters, which identify specific groups such as "families living in poverty" and "elderly or disabled residents" (Toronto) and those "who are unable to obtain safe and nutritious food for good health" due to "physical, economic, educational and other barriers" (London).

${ }^{13}$ For example, food-security initiatives endorsed by food charters, such as community kitchens, often do not address effectively the needs of families living in severe poverty (Bidwell, 2009; Engler-Stringer \& Berenbaum, 2005; 2007).
} 
food charters therefore blocks from view certain of its members while emphasizing others, such that the genre itself may preclude the very sorts of actions that might benefit all members of a given community, especially those most at risk of food insecurity.

Ultimately, the genre of Ontario food charters constitutes an ambiguous and shifting sense of who "community" is and the role that diverse community members and groups play in creating, implementing, and benefiting from the vision advanced within a given food charter. As we discuss below, these tensions appear to be tempered by the use of lists to articulate each community's set of core values for its food system; however, a close reading of these value-lists reveals underlying logical and ideological incongruities that may also limit their potential to enact the sort of actions in the food system that they envision.

\section{Articulating core values: Lists as quasi-logical arguments in food charters}

All but one of the 22 Ontario charters we analysed employs a list format to present the community's core values and priorities for its regional food system. This recurring formal feature of the genre both manifests and manages the incongruities that inform each charter's representation of community identity and community values. The list structure implies a hierarchical logic within the charter, a sense of careful taxonomic reasoning. However, as we argue below, these value-lists contain underlying tensions that could constrain the potential impact of food charters on food policy development and implementation. Analyzing lists as a rhetorical form within the food charter genre illuminates how the genre produces a sense of a shared, coherent communal vision despite the disparate and possibly conflicting principles and priorities that together compose this vision.

Community visions and values: How should a food system be?

Generally, each charter begins with an overarching statement of the community's goal or vision for its food system. Ranging from one or two sentences to several short paragraphs, the preamble typically describes the community's vision for a "healthy, just, and sustainable food system" (Waterloo Region, 2013) and declares its intention to work together to implement this "common vision" according to the principles outlined in the remainder of the document.

Following that opening statement, the charters are organized into lists of core values that emerge out of and support this vision. Typically, these lists contain the following value categories (though in varying order and phrasing):

- Health

- Education

- Economy

- Environment 
- Culture \& Community

- Social Justice

Most of the charters we analyzed present these headings either on their own or as bold, highlighted, or coloured text within longer value-statements, such as "Because we value/believe $x$ [value], we support y [action]” (see Figure 1). Under each of these core value-statements is a list of specific objectives or endpoints for the enactment of that value within food-related policy and practice. For example, in the Guelph-Wellington (2011) charter, under the value-statement "Because we value Health, we support..." (original emphasis here and below), the charter lists the following objectives:

- Public policy that recognizes food's contribution to physical, mental, spiritual, and emotional well-being.

- Neighbourhoods that encourage walk-able and bike-able access to healthy food.

- Strategies to prevent and manage chronic diseases through access to affordable healthy food. (Guelph-Wellington, 2011)

In the same charter, under the value-statement "Because we value Sustainable Economic Development, we support...” are the following objectives:

- Prioritizing production, processing, distribution, and consumption of local food.

- Promoting our region as a food, agricultural, and culinary destination.

- Advancing food and agriculture research and innovation for alternative food systems.

These lists organize the charter's overarching stated goal into categories and subcategories that seem to provide a map for the document's users to engage in effective action within the food system.

\section{Lists as quasi-logical arguments}

The use of lists to structure information within food charters, illustrated in the preceding section, provides an impression of coherence and compatibility among the diverse values included within them, thereby possibly obscuring logical and ideological inconsistencies among the different values and interests they espouse. In rhetorical terms, these lists function as what Perelman and Olbrechts-Tyteca (1969) call “quasi-logical arguments” which are rhetorical structures that "derive their persuasive strength from their similarity to... well-established modes of reasoning” such as formal logical proofs (p. 193). Quasi-logical arguments are association schemes that appear to demonstrate logical connections by linking two independent entities such that judgments about one are transferred to the other (van Rees, 2007, p. 1), thus conveying the 
impression "that the classes formed by the subdivision of a set are not ambiguous" (Perelman \& Olbrechts-Tyteca, 1969, p. 235).

Items in a list appear to be equal and of the same conceptual order (Ledin \& Machin, 2015), thus masking any logical inconsistencies among the items because the list format does not specify the interconnections among its parts (p. 469). Lists therefore imply careful reasoning via enumeration: they appear to enact a logical, orderly division of the whole into parts, which, in this case, is the division of the community's central vision for its food system into core values and objectives intended to implement that vision. In Ontario's food charters, the division of a community's overarching vision for its food system into component core values - which, in turn, are divided into component objectives or endpoints - suggests that those stated values and subvalues are logically connected and compatible with one another. This technique of vertical differentiation, in which each of the main parts is further subdivided into a taxonomic array, creates an impression of systematic depth and complexity (Spoel, 1997, p. 124).

Within the food charter genre, lists manage a tension between division and connection that appears integral to the ability of diverse community stakeholders to craft a "shared vision" for their food system. Each of the core values constitutes a separate part of the shared vision, whereas the list structure makes all parts appear to produce a whole, unified vision. However, in quasi-logical arguments such as lists, both the "parts” and the "whole” (and their attendant interrelations) may be less connected than they at first appear. As a meta-genre, the food charter appears to articulate a unified vision for the community's food system and a coherent set of guidelines for its enactment but, in reality, this vision may establish shaky, uneasy grounds for subsequent action.

\section{Wholes and parts: Incompatibilities in food charters' espoused values}

By dividing up a community’s vision for its food system into component values (which, in turn, are divided into component objectives or endpoints), the generic whole-part list structure of the food charter overlays the document with a sense of coherence that suggests the interconnectedness of each aspect of this vision but that also may obfuscate actual disparities and unspecified connections among its parts. If food charters are intended to inform the development of effective food policy, these disconnections and possible incompatibilities may limit their ability to effect meaningful action for all stakeholders involved, including not only those involved in their production but, more broadly, those affected by their enactment.

For example, the Waterloo Region (2013) food charter, which is fairly typical of the genre, contains potential inconsistencies across its core values and sub-values that that may inhibit its translation into effective food policy planning and implementation. The charter articulates five overarching core values:

1. connecting people to our local food system

2. community economic development 
3. access to healthy food

4. ecological health

5. integrated food policies at all levels of government

As a set of categories that aim collectively to enact the charter's shared vision of supporting "fair, environmentally sustainable, livable [sic], and economically profitable rural and urban communities," these five values appear to work in concert. However, drawing on recent scholarship in food studies, we find that many of the values sit in uneasy tension with each other.

Value 1 prioritizes local foods, for instance, whereas Value 3 emphasizes foods that are both accessible and healthy. These two values do not necessarily entail one another and may, in some cases, be openly contradictory: locally-produced foods are not ipso facto healthier, by virtue of either higher nutrient values (Frith, 2007; Vogt \& Kaiser, 2008, p. 251) or reduced chemical inputs such as fertilizer or pesticides (Born \& Purcell, 2006; Edwards-Jones, 2010; Hinrichs, 2003), than foods shipped from further away, nor are they necessarily financially or geographically accessible to everyone (Born \& Purcell, 2006; DuPuis \& Goodman, 2005; Guthman, 2011). Indeed, critics note how North American local food movements frequently foster an elitist mode of consumerism (e.g., "locavores”) rather than supporting food justice for all (Blue, 2009; Guthman, 2008; 2011).

Similarly, Value 1's emphasis on local food is not necessarily compatible with Value 4, which prioritizes ecological health: locally-produced food is not inherently more environmentally sustainable than food produced elsewhere (Born \& Purcell, 2006; EdwardsJones, 2010; Hinrichs, 2003). For instance, one frequently cited benefit of local food is that it reduces greenhouse gas emissions by reducing “food miles”, but transportation only captures a portion of a product's total emissions, which also include growing, processing, storing, and retailing (Born \& Purcell, 2006; Edwards-Jones, 2010; Hinrichs, 2003). In addition, food that is ecologically sound (Value 4) is not necessarily produced locally (Value 1), or healthier, or more accessible (Value 3). In some cases, climate is a significant factor in environmental impact (e.g., imported produce may require less irrigation or heating than local produce), whereas in others, more environmentally friendly food products are significantly more expensive.

Our analysis also revealed potential incompatibilities among the sub-points of individual value-statements, where the list format obscures logical gaps between the items it contains. Consider, for example, the Waterloo charter's third value-statement:

\section{we support access to healthy food}

- by protecting farmland from urban development

- by supporting policies and other initiatives that ensure that everyone has access to enough nutritious food.

Under the latter objective are listed five additional points that, by implication, add up to a fulsome notion of "access": "adequate incomes for everyone"; "local production and processing of foods"; "walk-able...access to venues that sell healthy foods”; "widespread availability 
of...locally produced and culturally appropriate food"; and "availability of healthy, affordable food choices in workplaces and public institutions." In this charter, the list and sub-list of objectives under Value 3 pose potential problems of logic that echo those we have described above: that locally produced and processed food is not necessarily more nutritious, and that local food is not necessarily more accessible or affordable by virtue of the proximity of its production. Additionally, this list leaves unclear the link between its two main objectives, "protecting farmland from urban development" and ensuring access to healthy food for all residents. These items do not necessarily entail each other and the list structure does not provide a framework for making those connections clear. Instead, the paratactic (i.e., grammatically disconnected) structure of the list format implies that the items are connected logically, even if they are not explicitly intended by their authors to appear so.

This illustrative analysis of the Waterloo food charter indicates that the genre's recurring list format fosters a "strategic ambiguity," in rhetorical terms (Burke, 1969, p. 66), which allows the multiple community sectors involved in the development of food charters to negotiate their diverse interests and objectives. At the same time, the examples we have discussed here indicate the possibly intractable challenge of aligning these diverse groups and interests into a logically and ideologically unified food-system vision. That is, the list format typical of the genre invests food charters with a sense of comprehensiveness, depth, and texture, as well as a visual nesting of parts under an organizing whole, that may obfuscate inconsistencies or tensions that exist among those parts. To the extent that the different values expressed in food charters map onto different instantiations of community, the value-list format may likewise obscure the diverse, possibly incompatible needs and priorities of the different community members to whom each charter is addressed (and, importantly, not addressed). Because a central purpose of the food charter genre is to constitute a shared community vision, as well as a shared sense of community, its rhetorical form occludes these differences. While this occlusion may function strategically to foster a shared vision that encourages community sectors to work together, it also may limit the potential of food charters to effectively motivate and guide "healthy, just, and sustainable" (Waterloo Region, 2013) food-system action.

\section{Conclusion}

In our view, a central socio-ideological function of the Ontario food charter genre is to create a sense of togetherness and compatibility within communities who must negotiate diverse needs, interests, and values. The genre manages to accomplish this, at least to some extent, through rhetorical techniques such as naming the community and listing component parts of the community's shared vision for its food system. Even if the various senses of "community" and the values that constitute its shared vision do not cohere logically, the food charter genre enacts a discursive space for a community to reflect not only on the kind of food system that it aspires to have, but also the kind of community that it aspires to be. As an aspirational genre, then, food 
charters are well-equipped rhetorically to accommodate tensions and incompatibilities among the differing needs, interests, and values of the various community members who produce them and to whom they are addressed.

We contend, therefore, that the meta-genre of the food charter, as recently enacted within the context of Ontario's regional Public Health Unit boundaries, is as much about community as it is about food. Further, its nature as an aspirational statement of values - both concerning food systems and concerning communities — makes it primarily an epideictic rather than a deliberative genre of rhetoric: although the food charter appears to direct future action (a deliberative motive), its main effect is praising and reinforcing the values of the present to audiences who are presumed already to share those values (an epideictic motive). Under this valence, the food charter's ability to direct future action is less assured than the genre itself suggests.

If food charters are intended to function as meta-policy guides for practical action, then the logical-ideological incongruities that emerge from their shifting senses of community and their unarticulated relations among core values may limit their effectiveness in fostering the kind of politically progressive and situationally coherent food policies and strategies that food-system activists are working hard to achieve. It is unclear, for example, how initiatives aimed primarily at regional economic development will ensure either food security for all residents or ecological health for the whole region, and yet food charters exhort Ontario communities to address all three of these goals together.

An important next stage of this research, therefore, is to investigate the food policy and food strategy genres that the food charter, as a meta-genre, is helping to spur in Ontario regional communities. As rhetorical-genre theorists point out, fully understanding the action of any particular genre requires exploring its complex and evolving relationships within broader genre networks (Bazerman, 1994; Berkenkotter, 2001). For example, the preceding analysis affords a critically generative perspective on implementation documents such as Your Guelph Wellington Food Charter Toolkit (2012), which organizes its action plan by (re)dividing the shared community identity and values of the charter document into five separate constituencies: Eaters, Growers, Businesses and Institutions, Policy Makers, and Community Food Projects. Although each part of the community may have a role to play in implementing the food charter vision, each constituency is addressed separately and is identified as having its own particular opportunities and responsibilities for action.

We mention this one example in closing to suggest the importance of further research on how the food charter as a meta-genre fosters the production of diverse genres in food policy and practical application for community food systems. Each of these proliferating genres will likely reconfigure who the community is and what values it holds for its food system. Exploring these diverse configurations can help us to understand why some kinds of community members and some kinds of community priorities receive greater attention than others in efforts to develop a healthy, just, and sustainable food system for all. 


\section{Acknowledgements}

We gratefully acknowledge the invaluable contributions of our research assistants Yvonne Kirkpatrick, Jenny Kliever, and Shaun Pett on this project. 
Appendix: Ontario Food Charters Summary Table of Genre Features

\begin{tabular}{|c|c|c|c|c|c|c|c|c|c|c|c|c|c|c|}
\hline 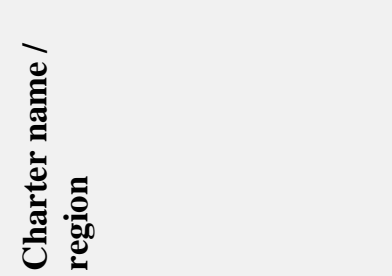 & 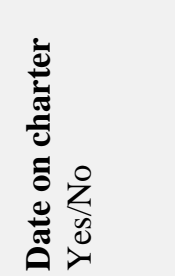 & 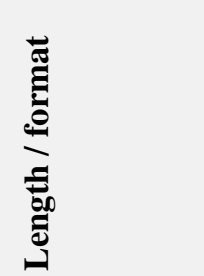 & 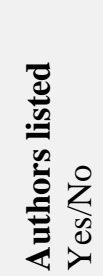 & 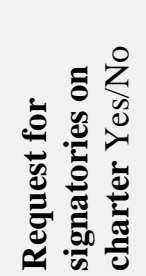 & 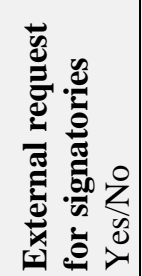 & 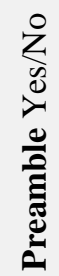 & 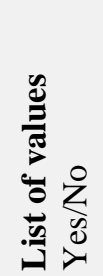 & 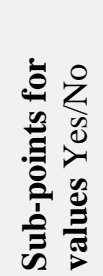 & 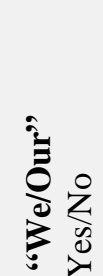 & 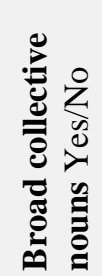 & 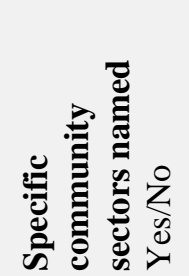 & 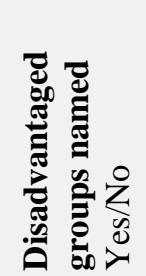 & 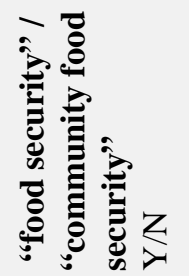 & 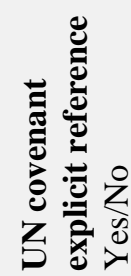 \\
\hline "Bruce Grey" & N (2014) & 6 (full page) & $\mathrm{Y}^{* *}$ & $\mathrm{~N}$ & $\mathrm{Y}$ & $\mathrm{Y}$ & $\mathrm{Y}$ & $\mathrm{Y}$ & $\mathrm{Y}$ & $\mathrm{Y}$ & $\mathrm{Y}$ & $\mathrm{Y}$ & $\mathrm{N}$ & $\mathrm{N}$ \\
\hline "City of Greater Sudbury" & Y (2004) & 1 (full page) & $\mathrm{Y}$ & $\mathrm{N}$ & $\mathrm{N}$ & $\mathrm{Y}$ & $\mathrm{Y}$ & $\mathrm{Y}$ & $\mathrm{Y}$ & $\mathrm{Y}$ & $\mathrm{Y}$ & $\mathrm{N}$ & $\mathrm{Y}(\mathrm{FS}, \mathrm{CFS})$ & $\mathrm{N}$ \\
\hline "Durham Region" & Y (2012) & 2 (full page) & $\mathrm{N}$ & $\mathrm{N}$ & $\mathrm{N}$ & $\mathrm{Y}$ & $\mathrm{Y}$ & $\mathrm{Y}$ & $\mathrm{Y}$ & $\mathrm{Y}$ & $\mathrm{Y}$ & $\mathrm{N}$ & Y (FS) & $\mathrm{N}$ \\
\hline "Elgin St-Thomas" & $\mathrm{N}(2012)$ & 2 (full page) & $\mathrm{N}$ & $\mathrm{N}$ & $\mathrm{N}$ & $\mathrm{Y}$ & $\mathrm{Y}$ & $\mathrm{Y}$ & $\mathrm{Y}$ & $\mathrm{Y}$ & $\mathrm{Y}$ & $\mathrm{N}$ & $\mathrm{N}$ & $\mathrm{Y}$ \\
\hline "Guelph-Wellington" & $\mathrm{N}(2011)$ & 1 (full page) & $\mathrm{Y}$ & $\mathrm{Y}$ & N/A & $\mathrm{Y}$ & $\mathrm{Y}$ & $\mathrm{Y}$ & $\mathrm{Y}$ & $\mathrm{Y}$ & $\mathrm{Y}$ & $\mathrm{Y}$ & $\mathrm{N}$ & $\mathrm{Y}$ \\
\hline "Halton" & Y (2010) & 1 (full page) & $\mathrm{N}$ & $\mathrm{N}$ & $\mathrm{Y}$ & $\mathrm{Y}$ & $\mathrm{Y}$ & $\mathrm{Y}$ & $\mathrm{Y}$ & $\mathrm{Y}$ & $\mathrm{Y}$ & $\mathrm{N}$ & $\mathrm{N}$ & $\mathrm{N}$ \\
\hline "Hamilton" & Y (2013) & 2 (pamphlet) & $\mathrm{Y}$ & $\mathrm{N}$ & $\mathrm{Y}$ & $\mathrm{Y}$ & $\mathrm{Y}$ & $\mathrm{Y}$ & $\mathrm{Y}$ & $\mathrm{Y}$ & $\mathrm{Y}$ & $\mathrm{Y}$ & Y (CFS) & $\mathrm{Y}$ \\
\hline "Huron County" & N (2015) & 4 (full page) & $\mathrm{Y}$ & $\mathrm{Y}$ & N/A & $\mathrm{Y}$ & $\mathrm{Y}$ & $\mathrm{Y}$ & $\mathrm{Y}$ & $\mathrm{Y}$ & $\mathrm{Y}$ & $\mathrm{N}$ & $\mathrm{N}$ & $\mathrm{N}$ \\
\hline "Kawartha Lakes" & N (2011) & 2 (full page) & $\mathrm{Y}$ & $\mathrm{N}$ & $\mathrm{N}$ & $\mathrm{Y}$ & $\mathrm{Y}$ & $\mathrm{Y}$ & $\mathrm{N}$ & $\mathrm{Y}$ & $\mathrm{Y}$ & $\mathrm{N}$ & Y (FS) & $\mathrm{N}$ \\
\hline $\begin{array}{l}\text { "Kingston, Frontenac, } \\
\text { Lennox \& Addington" }\end{array}$ & N (2012) & 2 (full page) & $\mathrm{Y}$ & $\mathrm{N}$ & $\mathrm{Y}$ & $\mathrm{Y}$ & $\mathrm{Y}$ & $\mathrm{Y}$ & $\mathrm{Y}$ & $\mathrm{Y}$ & $\mathrm{Y}$ & $\mathrm{Y}$ & $\mathrm{N}$ & $\mathrm{N}$ \\
\hline $\begin{array}{l}\text { "Leeds, Grenville \& } \\
\text { Lanark County" }\end{array}$ & N (2014) & 1 (full page) & $\mathrm{N}$ & $\mathrm{Y}$ & N/A & $\bar{Y}$ & $\mathrm{Y}$ & $\mathrm{Y}$ & $\mathrm{Y}$ & $\bar{Y}$ & $\mathrm{Y}$ & $\mathrm{N}$ & $\mathrm{N}$ & $\mathrm{N}$ \\
\hline "London" & N (2011) & 4 (full page) & $\mathrm{Y}$ & $\mathrm{N}$ & $\mathrm{N}$ & $\mathrm{Y}$ & $\mathrm{Y}$ & $\mathrm{N}$ & $\mathrm{N}$ & $\mathrm{Y}$ & $\mathrm{Y}$ & $\mathrm{Y}$ & $\mathrm{Y}(\mathrm{FS})$ & $\mathrm{Y}^{* * * *}$ \\
\hline "Northumberland County" & $N(2013)$ & 2 (pamphlet) & $\mathrm{Y}$ & $\mathrm{Y}$ & N/A & $\mathrm{Y}$ & $\mathrm{Y}$ & $\mathrm{Y}$ & $\mathrm{Y}$ & $\mathrm{Y}$ & $\mathrm{Y}$ & $\mathrm{N}$ & Y (FS) & $\mathrm{Y}^{* * * *}$ \\
\hline "Oxford County" & $\mathrm{Y}^{*}(2010)$ & 1 (webpage) & $\mathrm{Y}$ & $\mathrm{N}$ & $\mathrm{N}$ & $\mathrm{N}$ & $\mathrm{N}$ & $\mathrm{N}$ & $\mathrm{N}$ & $\mathrm{Y}$ & $\mathrm{Y}$ & $\mathrm{N}$ & $\mathrm{Y}(\mathrm{FS})$ & $\mathrm{Y}^{* * * * *}$ \\
\hline "Parry Sound \& Area" & $\mathrm{Y}^{*}(2015)$ & 1 (webpage) & $\mathrm{Y}$ & $\mathrm{N}$ & $\mathrm{Y}$ & $\mathrm{Y}$ & $\mathrm{Y}$ & $\mathrm{Y}$ & $\mathrm{Y}$ & $\mathrm{Y}$ & $\mathrm{Y}$ & $\mathrm{Y}$ & $\mathrm{N}$ & $\mathrm{N}$ \\
\hline "Sarnia-Lambton" & N (2011) & 1 (full page) & $\mathrm{N}$ & $\mathrm{Y}$ & N/A & $\mathrm{Y}$ & $\mathrm{Y}$ & $\mathrm{Y}$ & $\mathrm{Y}$ & $\mathrm{Y}$ & $\mathrm{Y}$ & $\mathrm{N}$ & $\mathrm{N}$ & $\mathrm{N}$ \\
\hline "Simcoe County" & $\mathrm{Y(2013)}$ & 4 (full page) & $\mathrm{Y}$ & $\mathrm{Y}$ & N/A & $\mathrm{Y}$ & $\mathrm{Y}$ & $\mathrm{Y}$ & $\mathrm{Y}$ & $\mathrm{Y}$ & $\mathrm{Y}$ & $\mathrm{N}$ & $\mathrm{Y}(\mathrm{FS})$ & $\mathrm{N}$ \\
\hline "Thunder Bay" & N (2008) & 1 (full page) & $\begin{array}{l}\mathrm{N}^{* *} \\
*\end{array}$ & $\mathrm{~N}$ & $\mathrm{~N}$ & $\bar{Y}$ & $\mathrm{Y}$ & $\bar{Y}$ & $\mathrm{~N}$ & $\mathrm{Y}$ & $\mathrm{Y}$ & $\mathrm{N}$ & Y (FS, CFS) & $\mathrm{N}$ \\
\hline "Toronto" & $\mathrm{N}(2001)$ & 4 (full page) & $\mathrm{N}$ & $\mathrm{N}$ & $\mathrm{N}$ & $\mathrm{Y}$ & $\mathrm{Y}$ & $\mathrm{Y}$ & $\mathrm{Y}$ & $\mathrm{Y}$ & $\mathrm{Y}$ & $\mathrm{Y}$ & $\mathrm{Y}(\mathrm{FS})$ & $\mathrm{Y}$ \\
\hline "Waterloo Region" & N (2013) & 2 (full page) & $\mathrm{Y}$ & $\mathrm{N}$ & $\mathrm{Y}$ & $\mathrm{Y}$ & $\mathrm{Y}$ & $\mathrm{Y}$ & $\mathrm{Y}$ & $\mathrm{Y}$ & $\mathrm{Y}$ & $\mathrm{N}$ & $\mathrm{N}$ & $\mathrm{N}$ \\
\hline "Windsor Essex County" & $\mathrm{N}(2014)$ & 2 (pamphlet) & $\mathrm{Y}$ & $\mathrm{N}$ & $\mathrm{N}$ & $\mathrm{Y}$ & $\mathrm{Y}$ & $\mathrm{Y}$ & $\mathrm{Y}$ & $\mathrm{Y}$ & $\mathrm{Y}$ & $\mathrm{N}$ & $\mathrm{N}$ & $\mathrm{N}$ \\
\hline "York" & $\mathrm{Y} \mathrm{(2013)}$ & 1 (full page) & $\mathrm{N}$ & $\mathrm{N}$ & $\mathrm{N}$ & $\mathrm{Y}$ & $\mathrm{Y}$ & $\mathrm{Y}$ & $\mathrm{Y}$ & $\mathrm{Y}$ & $\mathrm{Y}$ & $\mathrm{N}$ & $\mathrm{N}$ & $\mathrm{N}$ \\
\hline
\end{tabular}

* Date does not appear to be part of the food charter itself-it is located in the bottom right of the webpage.

** The charter names the "Bruce Grey Poverty Task Force" on the last page but it is unclear whether this is the author of the food charter.

*** City of Thunder Bay logo and signature of the Mayor appear on the charter, but they are not the document's authors.

**** Does not directly name the UN Covenant, but references the more recent 2009 World Food Summit on Food Security, hosted by the UN's Food and Agriculture Organization. 


\section{References}

Bazerman, C. (1994). Systems of genres and the enactment of social intentions. In A. Freedman \& P. Medway (Eds.), Genre and the new rhetoric (pp. 79-101). London: Taylor and Francis.

Bawarshi, A., \& Reiff, M.J. (2010). Genre: An introduction to history, theory, research, and pedagogy. West Lafayette: Parlor Press.

Berkenkotter, C. (2001). Genre systems at work: DSM-IV and rhetorical recontextualization in psychotherapy paperwork. Written Communication, 18, 326-349.

Bidwell, S. (2009). Food Security: A review and synthesis of themes from the literature. Paper prepared for Programme Area Four Community and Public Health. Christchurch: District Health Board / Te Poari Hauora ō Waitaha, New Zealand.

Born, B., \& Purcell, M. (2006). Avoiding the local trap: Scale and food systems in planning research. Journal of Planning Education and Research, 26, 195-207.

Blue, G. (2009). On the politics and possibilities of locavores: Situating food sovereignty in the turn from government to governance. Politics and Culture, 2, 68-79.

Burke, K. (1969). A grammar of motives. Berkeley: University of California Press.

Burke, K. (1966). Language as symbolic action: Essays on life, literature, and method. Berkeley: University of California Press.

Committee on World Food Security. (2013). Global strategic framework for food security \& nutrition. United Nations Food and Agriculture Organization. http://www.fao.org/fileadmin/templates/cfs/Docs1213/gsf/GSF_Version_2_EN.pdf

Derkatch, C. \& Spoel, P. (2015). Public health promotion of "local food": Constituting the selfgoverning citizen-consumer. Health: An Interdisciplinary Journal for the Social Study of Health, Illness and Medicine. Advance online publication.

DOI: $10.1177 / 1363459315590247$

Dillon Consulting Limited. (2013). Food charter discussion paper. North Bay Parry Sound District Health Unit. Retrieved from http://www.myhealthunit.ca/en/resources/Food_Charter_Discussion_Paper_FINAL_Revi sed_March_13_2014.pdf 
DuPuis, M., \& Goodman, D. (2005). Should we go "home” to eat? Toward a reflexive politics of localism. Journal of Rural Studies, 21, 359-371.

Edwards-Jones, G. (2010). Does eating local food reduce the environmental impact of food production and enhance consumer health? Proceedings of the Nutrition Society, 69(4), 582-591.

Engler-Stringer, R., \& Berenbaum, S. (2005). Collective kitchens in Canada: A review of the literature. Canadian Journal of Dietetic Practice \& Research, 66, 246-251.

Engler-Stringer, R., \& Berenbaum, S. (2007). Exploring food security with collective kitchens participants in three Canadian cities. Qualitative Health Research, 17, 75-84.

foodcoreLGL. (n.d.a) Food charter for United Counties of Leeds and Grenville and Lanark County. Retrieved from http://www.foodcorelgl.ca/_resources/food-charter.pdf

foodcoreLGL. (n.d.b). What is a food charter? Retrieved from http://www.foodcorelgl.ca/facts.html

Food Net Ontario. (n.d.). Food charters. Retrieved from http://foodnetontario.ca/policyadvocacy/ charters/

Frith, K. (2007). Is local more nutritious? Harvard School of Public Health Center for Health and the Global Environment. Retrieved from http://www.chgeharvard.org/resource/localmore-nutritious

Giltrow, J. (2001). Metagenre. In R. Coe, L. Lingard, \& T. Teslenko (Eds.), The rhetoric and ideology of genre: Strategies for stability and change (pp. 187-206). Cresskill, NJ: Hampton Press.

Guelph-Wellington Food Round Table. (2011). Guelph-Wellington food charter. Retrieved from http://www.gwfrt.com/wp-content/uploads/2012/06/GW_Food_Charter.pdf

Guelph-Wellington Food Round Table. (2012). Your Guelph-Wellington food charter tool kit. Retrieved from http://tfpc.to/municipal-food-policy/countydistrictregional-fpcs/guelphwellington-food-round-table-gwfrt

Guthman J. (2008). Neoliberalism and the making of food politics in California. Geoforum, 39, 1171-1183. 
Guthman, J. (2011). Weighing in: Obesity, food justice, and the limits of capitalism. Berkeley, CA: University of California Press.

Halton Food Council. (2010). Halton food charter. Retrieved from http://www.haltonfoodcouncil.ca

Hardman, M., \& Larkham, P.J. (2014). The rise of the 'food charter': A mechanism to increase urban agriculture. Land Use Policy, 39, 400-402.

Hinrichs, C.C. (2003). The practice and politics of food system localization. Journal of Rural Studies, 19, 33-45.

Jaquith, M. (2011). An assessment of Canadian food charters: Highlights and recommendations for the KFL\&A Healthy Eating Working Group. KFL\&A Public Health. Retrieved from http://foodpolicykfla.ca/An_Assessment_of_Canadian_Food_Charters.pdf

KFL\&A Healthy Eating Working Group. (2012). Kingston, Frontenac, and Lennox \& Addington food charter. Retrieved from http://foodpolicykfla.ca/kfla-food-charter/

Ledin, P., \& Machin, D. (2015). How lists, bullet points and tables recontextualize social practice. Critical Discourse Studies, 12(4), 463-481.

London, Ontario Child and Youth Network. (2011). London's Food Charter. Retrieved from http://londoncyn.ca/wp-content/uploads/2012/07/Londons-Food-Charter-FINAL.pdf

MacRae, R., \& Donahue, K. (2013). Municipal food policy entrepreneurs: A preliminary analysis of how Canadian cities and regional districts are involved in food system change. Toronto Food Policy Council / Vancouver Food Policy Council / Canadian AgriFood Policy Institute.

Martin, S.J., \& Andrée, P. (2014). From food security to food sovereignty in Canada: Resistance and authority in the context of neoliberalism. In P. Andrée et al. (Eds), Globalization and food sovereignty: Global and local change in the new politics of food (pp. 173-198). Toronto: University of Toronto Press.

McCarthy, L.P. (1991). A psychiatrist using DSM-III: The influence of a charter document in psychiatry. In C. Bazerman \& J. Paradis (Eds.). Textual dynamics of the professions (pp. 358-378). Madison, WS: University of Wisconsin Press. 
Metzger, M., \& Aurini, J. (2013). Investigating the role of food charters in the Canadian food justice movement: A case study of Waterloo, Ontario. University of Waterloo. Retrieved from http://www.wrfoodsystem.ca/studentresearch

Miller, C. (1984). Genre as social action. Quarterly Journal of Speech, 70,151-67.

Ontario Ministry of Health and Long-Term Care. (2014). Public health units. Retrieved from http://www.health.gov.on.ca/en/common/system/services/phu/default.aspx

Paré, A. (2001). Genre and identity: Individuals, institutions, and ideology. In R. Coe, L. Lingard, \& T. Teslenko (Eds.), The Rhetoric and Ideology of Genre (pp.57 - 71). Cresskill, NJ: Hampton.

Perelman, C.H., \& Olbrechts-Tyteca, L. (1969). The New Rhetoric: A Treatise on Argumentation Notre Dame. OH: Notre Dame University Press.

Power, E.M. (2008). Conceptualizing food security for aboriginal people in Canada. Canadian Journal of Public Health, 99, 95-97.

Runnels, V. (2012). Local food policies and charters in Canada: A collection and guide for analysis. Ottawa: Population Health Improvement Research Network, University of Ottawa.

Sarnia Lambton Food Coalition. (n.d.) Sarnia-Lambton food charter. Retrieved from http://www.sarnialambtonfoodcharter.com/

Schryer, C., \& Spoel, P. (2005). Genre theory, healthcare discourse, and professional identity formation. Journal of Business and Technical Communication, 19 (3), 249-278.

Spoel, P. (1997). Disciplinary and bodily decorum in eighteenth-century British elocution: A rhetorical study of works by Thomas Sheridan, John Walker, and Gilbert Austin (Unpublished PhD thesis). University of Waterloo, Waterloo, ON.

Spoel, P., \& Den Hoed, R.C. (2014). Places and people: Rhetorical constructions of 'community' in a Canadian environmental risk assessment. Environmental Communication: A Journal of Nature and Culture, 8 (3), 267-285.

Thunder Bay Food Action Network. (2008). Thunder Bay Food Charter. Retrieved from http://www.tbdhu.com/healthyliving/healthyeating/foodsecurity/fan.htm 
Toronto Food Policy Council. (2013). Thunder Bay Food Action Network (FAN). Retrieved from http://tfpc.to/municipal-food-policy/fpc-facilitated-by-gov/thunder-bay-food-actionnetwork-fan

Toronto Food Policy Council. (2001). Toronto’s Food Charter. Retrieved from http://tfpc.to/wordpress/wp-content/uploads/2011/10/Toroto_Food_Charter.pdf

Van Rees, M.A. (2007). Dialectical and rhetorical effects of dissociation. In H.V. Hansen et al. (Eds.). Dissensus and the search for common ground, CD-ROM (pp. 1-12). Windsor, ON: OSSA.

Vogt, R., \& Kaiser, L. (2008). Still a time to act: A review of institutional marketing of regionally-grown food. Agriculture and Human Values, 25, 241-255.

Waterloo Region Food System Roundtable. (2013). Waterloo Region food charter. Retrieved from http://www.wrfoodsystem.ca/food-charter

York Region Food Charter Working Group. (2012). Taking root: York Region food charter consultations. Aurora, ON: York Region Food Network. Retrieved from http://yrfn.ca/wp-content/uploads/2011/12/YRFC-Consultation-Report-2012.pdf 